\title{
The Measurement of Impulse Buying Toward Emotional Responses
}

\author{
Joseph M J Renwarin \\ Institut Teknologi dan Bisnis Kalbis Indonesia \\ ${ }^{*}$ Corresponding Author: \\ Email: joseph.renwarin@kalbis.ac.id
}

\begin{abstract}
.
The objective of this research aims to know the influence of sales promotions and store atmosphere towards impulse buying with emotional responses as an intervening variable. The research method explores the primary data using quantitative approach for analysis. The research data of 310 respondents, come from the questionnaire disbursement by google form. The data analysis using SPSS 23.0 and SEM methods (Structural Equation Modeling) 88.0 LISREL. The research results of the analysis stated that sales promotions has no effect towards impulse buying with $t$ value $1.28(<1.967)$; store atmosphere has no effect towards impulse buying with a t value $-2.25(<1.967)$; emotional responses affect the impulse buying with $t$ value 4.56 (> 1.967); sales promotion affect to emotional responses with $t$ value 7.68 (> 1.96) and store atmospheric affect on impulse buying with value tof $10.12(>1.967)$.
\end{abstract}

Keywords: Sales Promotions, Store Atmosphere, Emotional Responses, Impulse Buying

\section{INTRODUCTION}

The turnover of national retail sales in Indonesia in 2016 reached the highest point along its growth history, where in that year Indonesia occupied the fifth rank in the Global Retail Development Index (GRDI) according to A.T Kearney (2016), a consultant company for global management with total turnover of national retail sales amounting USD 324 billion. In the previous years, Indonesia occupied the 12th rank in 2015 and the 15th rank in 2014. The growth of retail business in Indonesia illustrates Indonesian people's high consumption of goods offered by retailers. This makes Indonesia a potential market for such a business model to continuously grow, creating a tight competition in this country among retailers, both foreign and local. Therefore, retailers need an appropriate strategy to run their business, responding people's needs and wants, and to build sustainable competitive advantages. One of the strategies commonly implemented by retailers is retail mix strategy which consists of some or all elements, namely location, purchase/service procedures, merchandising (goods/services being offered), price, store atmosphere, customer services, and promotion method. These elements may become the attractiveness for retail business customers. 
One of the industries in Indonesia which consistently increases its sales is leather and footwear industry. This shows an interesting opportunity for leather goods and footwear retailers from both domestic and foreign countries to grow and develop in Indonesia. This business opportunity is also realized by the biggest shoe retailer in the Western Hemisphere, namely Payless Shoesource which came to Indonesia in 2011. Based on the data of the growth of non-oil and gas processing industry issued by Statistical Data Center, the footwear sales in Indonesia in 2011 reached IDR 21.8 billion (Indonesia Government Statistical Berau, 2017). Payless Shoesource confidently enters shoe retail market in Indonesia by cooperating with Mitra Adiperkasa Group, a franchise company, to develop the retail network of Payless in several places in Indonesia. In running its business, Payless Shoesource has implemented some strategies to create competitive advantages, one of them is retail mix strategy. Payless exists in Indonesia offering a concept of store which differs from common shoestore, where Payless displays its products based on the foot size, aiming to provide the visitors with easiness to find the product suitable with their foot size. This concept surely makes the store atmosphere of Payless different. In addition to different store atmosphere that Payless Shoesource creates, it also implements the strategies commonly implemented by other retailers, for example promotion activities, which one of them is sales promotion. The implementation of these strategies are expected to enhance the possibility of purchase which will give a short term benefit in the form of sales increase and long term benefits in the forms of value creation and competitive advantages. That is why the author is interested and focuses this study on two aspects of Payless Shoesource's retail mix, namely store atmosphere and promotion method, i.e. sales promotion. Through strategy implementation in these two aspects, Payless expects consumers' response, in this case emotional response to the shopping environment so that it will affect their purchase decision makings, one of them is impulse buying decision.

\section{METHODS}

Analysis unit is the smallest unit of a research object desired by the researcher as the classification of data collecting. The research method in this study is quantitative approach; data collecting is carried out by distributing questionnaires through Google form; data analysis is quantitative or using statistics to test the hypothesis (Efferin, 2004:55). The Population of this research are Payless Shoesource visitors in Jakarta and suburb area. Sampling was done by Nonprobability Sampling Design technique with purposive sampling. It was found that the sample of this research was 310 respondents. The respondents in this study are visitors and consumers who have known, visited, or bought a product in Payless Shoesource.

\section{Respondent Profile Anslysis by Sex}

http://ijstm.inarah.co.id 
From the data respondent distribution by sex, it is found that the percentage of female respondents is $75 \%$ and male respondents is $25 \%$. This indicates that the visitors and consumers of Payless Shoesources are dominated by female people.

\section{Respondent Profile Analysis by Age}

It is found that the respondents by age group have the following percentages 10-15 years as many as $2 \%, 16-25$ years as many as $94 \%, 26-35$ years as many as $2 \%, 36-45$ years as many as $1 \%$, and $>45$ years as many as $1 \%$. Thus, it seems that people in the age of adolescent to adult (16-25 years) become the target market of Payless Shoesources and the dominant respondents in this study.

\section{Respondent Profile Analysis by Occupation}

The respondents in this study are also categorized based on the criterion of occupation. The distribution of respondents by occupation is found as follows: Student 18\%, College Student 54\%, Employee 20\% and Entrepreneur 8\%. This indicates that the visitors and consumers of Payless Shoesource are dominated by college students, followed by employees and students, where those people are really the market segment of Payless Shoesources.

\section{RESULT AND DISCUSSION}

\section{Result of Structural Equation Model (SEM)}

After carrying out validity test, reliability test and classic assumption test and all the instruments of this study are stated as valid and the data is free from the symptoms of classic assumption, then the next test is to know the influence degree of sales promotion and store atmosphere variables on impulse buying with emotional responses as the intervening variable. The test is done using structural equation model (SEM) method and the outputs of structural equation are obtained:

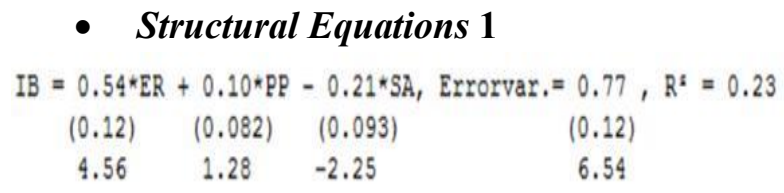

The first structural equation indicates that sales promotion (PP), store atmosphere (SA) and emotional responses (ER) variables simultaneously influence impulse buying (IB) with the coefficient of determination value 0.23 . It means the simultaneous influence degree of sales promotion, store atmosphere and emotional responses variables on impulse buying is $23 \%$, and the rest of $77 \%$ is influenced by other factors not examined in this study. The small coefficient of determination shows that sales promotion, store atmosphere and emotional responses variables are simultaneously not effective in affecting the impulse buying of Payless Shoesources visitors. 


\section{- Structural Equations 2}

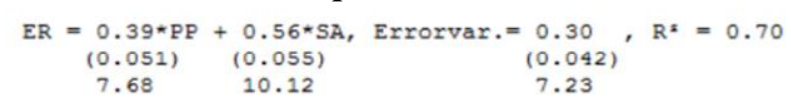

The result of the second structural equation shows the influence of sales promotion and store atmosphere variables on emotional responses variable with the coefficient of determination value 0.70 . It means the simultaneous influence degree of sales promotion and store atmosphere variables on emotional responses variable is $70 \%$, while the rest of $30 \%$ is influenced by other factors not examined in this study. The big coefficient of determination value indicates that sales promotion and store atmosphere are simultaneously effective in affecting the emotional responses of Payless Shoesource visitors, where emotional responses in this study act as the intervening variable.

From those two structural equations above, it can be known the direct influence, indirect influence and total influence of each variable tested as follows:

\section{- Analysis on Direct Influence}

The direct influence of exogenous latent variables (KSI), namely sales promotion and store atmosphere, on the endogenous latent variables (ETA), namely emotional responses and impulse buying, can be seen from the values of Gamma $(\gamma)$ and Beta $(\beta)$ in the structural equation, where $\beta$ is the coefficient of endogenous variable influence on endogenous variable whereas $\gamma$ is the coefficient of exogenous variable influence on endogenous variable. So, the direct influence of sales promotion on impulse buying $\left(\gamma_{\mathrm{PP}, \mathrm{IB}}\right)$ in this study is 0.10 and the direct influence of store atmosphere on impulse buying $\left(\gamma_{\mathrm{SA}, \mathrm{IB}}\right)$ is -0.21 . Whereas the direct influence of emotional responses on impulse buying $\left(\boldsymbol{\beta}_{\mathrm{ER}, \mathrm{IB}}\right)$ is 0.54 .

\section{- Analysis on Indirect Influence}

In addition to direct influence, this study also examines the indirect influence of exogenous latent variables (KSI), namely sales promotion and store atmosphere on endogenous latent variable (ETA), namely impulse buying, through another endogenous latent variable (ETA), namely emotional responses, through the following calculation:

1. Sales promotion on impulse buying through emotional responses $=\left(\boldsymbol{\gamma}_{\mathrm{PP}, \mathrm{ER}}\right) \times\left(\boldsymbol{\beta}_{\mathrm{ER}, \mathrm{IB}}\right)$ $=0.39 \times 0.54=0.21$.

2. Store atmosphere on impulse buying through emotional responses $=\left(\gamma_{\mathrm{SA}, \mathrm{ER}}\right) \mathrm{x}$ $\left(\boldsymbol{\beta}_{\mathrm{ER}, \mathrm{IB}}\right)=0.56 \times 0.54=0.30$.

\section{- Analysis on Total Influence}

Total influence can be known by summing up the direct influence and indirect influence that have been obtained. So, the total influence of each exogenous latent variable (KSI) on endogenous latent variable (ETA) in this study is as follows:

- PP on IB is 0.31 .

- $\quad \mathrm{SA}$ on IB is 0.09 . 
- $\quad$ PP on ER is 0.39 .

- SA on ER is 0.56.

\section{F. Results of Hypothetical Test}

- Sales promotion variable does not positively and significantly influence impulse buying variable with $\mathrm{t}_{\text {statistics }}<\mathrm{t}_{\text {table, }}$, that is $1.28(<1.967)$.

- Store atmosphere variable does not positively and significantly influence impulse buying either with $\mathrm{t}_{\text {statistics }}<\mathrm{t}_{\text {table, }}$, that is $-2.25(<1.967)$.

- Emotional responses variable positively and significantly influence impulse buying variable with $t_{\text {statistics }}>t_{\text {table }}$, that is $4.56(>1.967)$.

- Sales promotion variable positively and significantly influences emotional responses variable with $t_{\text {statistics }}>t_{\text {table, }}$, that is $7.68(>1.967)$.

- Store atmosphere variable positively and significantly influences emotional responses variable with the resulted value of $10.12(>1.967)$.

\section{CONCLUSION}

From the series of tests that have been done to know the influence of sales promotion and store atmosphere on impulse buying with emotional responses as the intervening variable in Payless Shoesource Jakarta and suburb area using the tools of statistical analysis as well as the above discussion and analysis, then conclusion can be made as follows:

1. Sales promotion positively but unsignificantly influences the impulse buying of Payless Shoesources visitors with the value of beta coefficient 0.10 and $t_{\text {statistics }}(1.28)<$ $\mathrm{t}_{\text {table }}(1.967)$.

2. Store atmosphere negatively and unsignificantly influences the impulse buying of Payless Shoesources visitors with the value of beta coefficient -0.21 and $t_{\text {statistics }}(-2.25)$ $<\mathrm{t}_{\text {table }}(1.967)$.

3. Emotional responses positively and significantly influences the impulse buying of Payless Shoesources visitors with the value of beta coefficient 0.54 and $t_{\text {statistics }}(4.56)>$ $t_{\text {table }}(1.967)$.

4. Sales promotion positively and significantly influences the emotional responses of Payless Shoesources visitors with the value of beta coefficient 0.39 and $t_{\text {statistics }}(7.68)>$ $t_{\text {table }}(1.967)$.

5. Store atmosphere positively and significantly influences the emotional responses of Payless Shoesources visitors with the value of beta coefficient 0.56 and $t_{\text {statistics }}$ $(10.12)>t_{\text {table }}(1.967)$.

\section{Managerial Implication}

Sales and store atmosphere promotions do not directly influence the impulse buying of Payless visitors, but sales promotions and store atmosphere will have more influence on impulse buying when passing emotional responses. Therefore, it is 
important for Payless to improve situations that will build up the emotional response of visitors to be able to lead them to buying actions in this case impulse buying. In terms of sales promotion, for the discounted dimension, Payless needs to increase or expand the delivery media related to the ongoing promotion. From the shopping coupon dimension, Payless needs to increase the intensity of giving coupons more often. As for the direct sales dimension, Payless needs to approach sales directly to consumers more effectively, not only through offers made by cashiers at the point of payment. In terms of store atmosphere, for the uniqueness dimension, Payless needs to improve the unique design of the room. From the dimensions of the fixture (Paying), Payless needs to reorganize the supporting tools in the store to make it more pleasing to the eye. While from the side of ensemble display (product categorization), Payless needs to increase the attractiveness of the categorization that has been done. In terms of emotional responses, for the dimension of pleasure, Payless needs to create an atmosphere that can provide a calm feeling while in the store. While for the arousal dimensions of Payless visitors, Payless needs to improve its ability to foster a feeling of enthusiasm when visitors are at Payless. And for the dominance dimension, Payless needs to provide attractive offers delivered using loudspeakers to attract the public to visit Payless. In terms of impulse buying, for the dimension of spontaneity, Payless needs to increase the attractiveness of the display, so it doesn't seem monotonous. From the dimensions of compulsion strength, Payless needs to improve its ability to make visitors reckless in buying products by improving product quality, creating a good atmosphere and attractive offers. Whereas from the dimensions of excitement and stimulation, Payless needs to increase external stimulation

Such as seduction or complete information provided by a salesperson related to a product that will convince prospective buyers to take action to purchase.

Researchers have poured substantial theories into each variable, but there are still limitations in various things so that things that need to be considered and improved and improved for future researchers are find, including:

1. Specify the population so that the sampling can be more directed.

2. Manually distributing questionnaires (not only using google form).

3. Looking for variable dimensions that are more precise and in accordance with the characteristics of the research object.

4. Confirming the indicators formed.

5. Test the same respondent with different time periods.

6. Take data during peak season.

7. Looking for intermediate variables other than emotional responses or changing management performance measurements other than impulse buying, because after being tested together with the variable $\mathrm{x}$, namely sales promotion and store atmosphere, the value of the determination coefficient (R2) is low, which is only 0.23 . 8. Using the same model but with different research objects. 


\section{REFERENCES}

[1] A.T Kearney. (2016). Global Research Development Index. Retrieved in January 2017, from https://www.atkearney.com/consumer-products-retail/global-retail-developmentindex/full-report/-/asset_publisher/oPFrGkbIkz0Q/content/global-retail-expansion-at-acrossroads/10192

[2] Badan Pusat Statistik (Indonesia Center of Statistical Berau). (2017). Retrieved in February 2017, from https://www.bps.go.id/linkTable Dinamis/view/id/827

[3] Berman, B., \& Evans, J. R. (2010). Retail Management (11th ed.). New Jersey: Prentice Hall.

[4] Efferin, S. (2004). Research Method. Jakrta: Ghalia Indonesia.

[5] Ferdinand, A. (2000). Structural Equation Modeling in Management Research. Semarang: BP Universitas Diponegoro.

[6] Ghazali, I. (2001). Multivariate analysis Aplication with SPSS Program. Semarang: Badan Penerbit Universitas Diponegoro.

[7] Ghozali, I. (2005). Multivariate analysis Aplication with SEM Program. Semarang: Badan Penerbit Universitas Diponegoro.

[8] Ghozali, I. (2011). Multivariate analysis Aplication with SPSS Program. Semarang: Badan Penerbit Universitas Diponegoro.

[9] Hatane, S. (2007). "Emotional response to buying impulse on customer online with the buying power as mediating variable, Jurnal Manajemen.".[online]. Jurnal Manajemen. Retrieved in February 2017

[10] Marnat, G. G. (2009). Handbook of Psychological Assessment. Pustaka Pelajar. Yogyakarta

[11] Mowen, J. C., \& Minor, M. (2001). Cosnumer Behavior, : Erlangga. Jakarta

[12] Sakara, A., \& Alhassan, F. (2014). An Assessment of Sales Promotion As Effective Tool for Customer Retention in Telecommunication Indstry of Ghana. II(10). Retrieved in February 2017, from http://ijecm.co.uk/wp-content/uploads/2014/10/21038.pdf 